\title{
FORMULATION, STANDARDIZATION, AND EVALUATION OF POLYHERBAL DISPERSIBLE TABLET
}

\section{HARIKESH MAURYA, TIRATH KUMAR ${ }^{*}$}

\author{
Department of Pharmaceutical Sciences, Kumaun University, Bhimtal Campus, Bhimtal, Nainital, Uttarakhand, India
} Email: kumart2@yahoo.co.in

Received: 03 Oct 2018, Revised and Accepted: 19 Nov 2018

\section{ABSTRACT}

Objective: The study was designed as formulation, standardization, and evaluation of polyherbal dispersible tablet prepared for the management of kidney disorders. To overcome the problem of dyspepsia in geriatric patients by the use of polyherbal dispersible tablets.

Methods: Dispersible tablets were prepared using aqueous root extract powder of the selected plant viz. A. officinalis, B. diffusa, $C$. papaya, C. fistula, C. intybus, F. hispida, F. indica, C. nurvala, $S$. virgaurea, and $V$. negundo with the help of superdisintegrant addition technique using crospovidone, sodium starch glycolate and croscarmellose sodium in different percentage. Evaluation assessments such as the substantial test, weight variation, hardness, friability, content uniformity, disintegration, in vitro dispersion, stability study and IR compatibility were carried out.

Results: Micromeritics of extracts powder were determined for all formulation, which signifying good flow properties. The substantial examination was established, which comply with official requirements for uniformity test, and the drug content was close to $100 \%$ in all formulations. Disintegration time was observed for all formulation in which the polyherbal formulation-3 (PHF-3) showing $1.10 \pm 0.10$ min; during in vitro dispersion time, all formulation showed appropriate dispersion in which the PHF-3 captivating $2.00 \pm 0.45$ min only. The IR compatibility shows none chemical interaction between the extracts and excipients.

Conclusion: The PHF-3 showed satisfactory disintegration and in vitro dispersion time due to crospovidone and reported as the best formulation. The stability study and IR compatibility validate the PHF may represent new easily swallow dispersible tablet that may enhance drug permeability and advance bioavailability for nephrotic patients.

Keywords: Polyherbal dispersible tablet, Micromeritics, Dispersion time, Superdisintegrants, Crospovidone, IR compatibility

(C) 2019 The Authors. Published by Innovare Academic Sciences Pvt Ltd. This is an open access article under the CC BY license (http://creativecommons.org/licenses/by/4.0/) DOI: http://dx.doi.org/10.22159/ijap.2019v11i1.30113

\section{INTRODUCTION}

The current trends for surviving long and healthy life entirely dependent on the traditional medication systems in which Ayurveda is one of the most favorable systems because of it possess several natural elements to eliminate the critical causes of the disease by restoring the equilibrium and preventing further reoccurrence [1]. WHO estimated that around $80 \%$ of the world's populations still trusting in traditional or Ayurvedic medicines for their healthy survival of life [2]. The Indian philosophy behind Ayurveda is to prevent unnecessary suffering of survival when curing the human ailments and also well-known for the significant biodiversity centers through concerning 45,000 herbal plant species out of which about 15,000 medicinal plants have been recorded to curing different human ailments by using single or multiple herbs for the complete elimination of disease [3].

The combination of various herbs (polyherbal) in a particular ratio will give a desirable therapeutic effect because the potent phytochemical constituents of individual plants are inadequate to achieve the beneficial effect $[4,5]$. The polyherbal formulation contains two or more herbs with different phytoconstituents possessing similar or dissimilar therapeutic potential have been collectively producing desirable effects during the management of human ailments $[6,7]$. The popularity of the polyherbal formulation is outstanding because of their wide therapeutic range i.e., effective at a low dose and safe at high dose, though produces fewer side effects whilst misused $[8,9]$.

The various parts used in the Ayurvedic medicine are the seed, root, bark, stem, gum, leaves, flowers, fruit, etc. of the plants $[10,11]$. The present research work designed to formulate and evaluate a novel polyherbal dispersible tablet containing aqueous root extracts of some selected plants possessing active phytoconstituents which were scientifically proven for the management of Glomerulonephritis [12] The name of these selected plants for the study viz. Angelica officinalis (Umbelliferae), Boerhavia diffusa (Nyctaginaceae), Carica papaya (Caricaceae), Cassia fistula (Fabaceae), Cichorium intybus (Asteraceae),
Ficus hispida (Moraceae), Fumaria indica (Fumariaceae), Crataeva nurvala (Capparidaceae), Solidago virgaurea (Asteraceae), and Vitex negundo (Verbenaceae). The quantity of drugs used in the formulation was considered by their drug tolerance study and effective dose on the basis of toxicity studies report. The equal amount of extract powder, $25 \mathrm{mg}$ has been used in this formulation for preparing polyherbal dispersible tablet as active constituents $[13,14]$.

\section{MATERIALS AND METHODS}

\section{Collection and authentication}

The medicinal plants used in the study were purchased from the local market of Khari Baoli, New Delhi, India. Fresh and shade dried roots of all selected plants have been authenticated by Botanical Survey of India, the Northern regional center 192, Kaulagarh Road, Dehradun, Boucher No: BSI/NRC/Tech. (Ident.)/2012-13/755.

\section{Preparation of extract}

The collected roots of the polyherbal plant were cleaned, dried under shade and crushed by a mechanical grinder. The powdered roots of each selected plants $(1000 \mathrm{~g})$ were poured in distilled water until the reach of complete exhaustion. Successive extracts were separately filtered by using Whatman filter paper and concentrated at an appropriate temperature $\left(40^{\circ} \mathrm{C}\right)$ on a rotary evaporator and dried under freeze drier. The percentage yield was found between $20-25 \%(w / w)$ respectively, and the final dried powder was stored in a closed container at a cool place [15].

\section{Characterization of powder}

The biologically potent polyherbal extract powder with a stand for varied physical properties and micromeritic properties. Extract powdered are heterogeneous because it was composed of individual particles of different sizes and shapes randomly interspersed with air spaces and becomes more complicated with polyherbal [16, 17]. Measurements were carried out in triplicate for each formulation and presented as the average \pm standard deviation (SD). 


\section{Angle of repose}

The flow properties of thoroughly mixed all polyherbal extract powder in the formulation were determined by calculating the angle of repose by the fixed height method. A funnel with $10 \mathrm{~mm}$ in diameter of the bottom was fixed at the height of $2 \mathrm{~cm}$ over the plain and smooth surface. About $10 \mathrm{gm}$ of a thoroughly mixed sample was slowly passed beside the wall of the funnel until the tip of the pile formed and touches the bottom of the funnel. A rough circle drowned around the pile base, and the radius of the powder cone was measured [18]. The angle of repose was calculated by the average radius using the following formula given as eq. 1 .

$$
\operatorname{Tan} \theta=\frac{\mathbf{h}}{\mathbf{r}}
$$

Where,

$$
\begin{aligned}
& \theta=\text { angle of repose } \\
& \mathrm{h}=\text { height of the pile } \\
& \mathrm{r}=\text { average radius of the powder cone }
\end{aligned}
$$

\section{Bulk density}

The bulk densities (BD) of polyherbal powder mixture were determined by pouring gently $25 \mathrm{gm}$ of sample mixture through a glass funnel into a $100 \mathrm{ml}$ graduated cylinder. The initial volumes occupied by the sample were recorded. The bulk density was calculated by using the following formula given as eq. 2 .

$$
\mathrm{BD}=\frac{\text { weight of the powder }(\mathrm{g})}{\text { volume occupied by the powder }(\mathrm{ml})}
$$

\section{Tapped density}

The tapped densities (TD) of polyherbal powder mixture were determined by pouring gently $25 \mathrm{gm}$ of sample mixture through a glass funnel into a $100 \mathrm{ml}$ graduated cylinder. The cylinder was tapped from the height of 2 inches until a constant volume obtained and then the average value of all formulation reported. The final volume occupied by the sample after tapping were recorded and tapped density calculated by using the formula given as eq. 3 .

$$
\mathrm{TD}=\frac{\text { weight of the powder }(\mathrm{g})}{\text { tapped volume occupied by the powder }(\mathrm{ml})}
$$

\section{Compressibility}

The Carr's compressibility gives a useful empirical guide. The compressibility of the polyherbal powder mixture was calculated by comparing the bulk density and tapped density. The percentage compressibility of all formulation was calculated as eq. 4 .

$$
\text { Carr's index }=\frac{\mathrm{TD}-\mathrm{BD}}{\mathrm{TD}} \times 100
$$

\section{Hausner's ratio}

It also shows densification of herbal powder mixture which may result from the vibration of the feed hopper, which was calculated by using the formula given in eq. 5 .

$$
\text { Hausner's ratio }=\frac{\mathrm{TD}}{\mathrm{BD}}
$$

Lower Hausner's ratio-Better flowability, Higher Hausner's ratioPoor flowability $[18,19]$.

\section{Preparation of polyherbal dispersible tablet}

Polyherbal dispersible tablets were prepared separately through geometrical dilution mixture with direct compression method (Punching machines, Cadmach CMS-15 No. H/513/11-12) by using different ingredients, disintegrating agents, talc, etc. as the composition of these formulations and denoted by PHF-1 to PHF-9. All the ingredients were passed through a mesh sieve no. 120 and then mixed each other by using geometrical dilution method to maintain uniformity. Powder mixtures possess good flow properties and good packing ability; therefore, the mixtures were directly compressed [20].

\section{Evaluation of polyherbal dispersible tablet \\ Drug content uniformity test}

From each formulation, 20 tablets were taken, weighed and thoroughly triturated. The sufficient powder equivalent to $250 \mathrm{mg}$ of the drug was accurately weighed and diluted in $300 \mathrm{ml}$ of $0.1 \mathrm{~N} \mathrm{HCl}$ for $10 \mathrm{~min}$ with vigorous shaking. Further, this prepared mixture was diluted with $0.1 \mathrm{~N} \mathrm{HCl}$ to produce $400 \mathrm{ml}$ and then filtered. $10 \mathrm{ml}$ of this filtrate was diluted to $100 \mathrm{ml}$ with distilled water, and the absorbance was measured at an appropriate wavelength, i.e., $\lambda_{\max }$ 200-400 nm using UV spectrophotometer [21].

\section{Disintegration time}

From each formulation 6 polyherbal dispersible tablets were randomly selected to determine the disintegration time. The acidic buffer ( $\mathrm{pH}$ 1.2) used as disintegration medium and temperature was maintained at $37 \pm 0.5{ }^{\circ} \mathrm{C}$. The average disintegration time of six tablets was noted down for calculation [22].

\section{Dispersion time}

In vitro dispersion time of polyherbal dispersible tablet was measured by dropping the tablet in a beaker containing $100 \mathrm{ml}$ of normal water. Two tablets from each formulation were randomly selected and in vitro dispersion time was determined. A smooth dispersion was produced, which passes through a sieve screen with a nominal mesh aperture of $710 \mu \mathrm{m}[23,24]$.

\section{In vitro dissolution study}

The dissolution testing of polyherbal medicines become difficult to oversee authority requirements due to widely varying constituents. The ingredients of polyherbal medicinal products often cover a mixture of multiple herbal constituents; dissolution method development is much more complex than for defined single constituent [25].

\section{Stability studies}

Accelerated stability study was carried out as per ICH guidelines for polyherbal combination to check the physical, chemical and physiological property of prepared formulation in a short period. The optimized PHF was subjected to accelerated stability studies at three different conditions of temperature and relative humidity i.e., $25^{\circ} \mathrm{C} / 60 \% \mathrm{RH}, 30^{\circ} \mathrm{C} / 65 \% \mathrm{RH}$ and $40^{\circ} \mathrm{C} / 75 \% \mathrm{RH}$ for $3 \mathrm{mo}$ [26].

\section{FTIR analysis of polyherbal combination}

Fourier transform infrared (FTIR) spectrum of herbal extracts was subjected to determine the identification of the compound and compatibility of the drug with other excipients used in the formulation of polyherbal dispersible tablets. The spectrum of IR helps in the identification of a compound based on the existence of different functional groups [27, 28].

\section{RESULTS AND DISCUSSION}

\section{Characterization of powder}

The basic characterization of powder and micromeritic properties of formulations containing polyherbal aqueous root extracts powder used for preparing dispersible tablets mentioned in table 1.

\section{Formulation and characterization of tablets}

Polyherbal dispersible tablets were compressed each of $550 \mathrm{mg}$ weight on a 10-station Mini Press-I rotary tablet compression machine fitted with $12 \mathrm{~mm}$ punches size. None tablet manufacturing defects like capping, lamination, and chipping were observed (table 2). 
Table 1: Micromeritic parameters of polyherbal aqueous root extracts powder

\begin{tabular}{|c|c|c|c|c|c|}
\hline Formulation Code & $\begin{array}{l}\text { Bulk density } \\
(\mathrm{gm} / \mathrm{ml})\end{array}$ & $\begin{array}{l}\text { Tapped density } \\
\text { (gm/ml) }\end{array}$ & $\begin{array}{l}\% \\
\text { Compressibility }\end{array}$ & $\begin{array}{l}\text { Hausner } \\
\text { Ratio }\end{array}$ & $\begin{array}{l}\text { Angle of } \\
\text { Repose }\left({ }^{\circ}\right)\end{array}$ \\
\hline PHF-1 & $0.38 \pm 0.05$ & $0.53 \pm 0.08$ & 28.30 & $1.39 \pm 0.14$ & $26.48 \pm 1.02$ \\
\hline PHF-2 & $0.42 \pm 0.04$ & $0.55 \pm 0.06$ & 21.82 & $1.31 \pm 0.11$ & $26.24 \pm 1.32$ \\
\hline PHF-3 & $0.35 \pm 0.03$ & $0.49 \pm 0.07$ & 28.57 & $1.40 \pm 0.13$ & $24.35 \pm 1.00$ \\
\hline PHF-4 & $0.40 \pm 0.06$ & $0.50 \pm 0.06$ & 20.00 & $1.25 \pm 0.09$ & $30.20 \pm 2.01$ \\
\hline PHF-5 & $0.45 \pm 0.04$ & $0.56 \pm 0.08$ & 19.64 & $1.24 \pm 0.10$ & $32.12 \pm 1.82$ \\
\hline PHF-6 & $0.38 \pm 0.07$ & $0.50 \pm 0.07$ & 24.00 & $1.32 \pm 0.08$ & $26.50 \pm 1.22$ \\
\hline PHF-7 & $0.43 \pm 0.06$ & $0.52 \pm 0.05$ & 17.31 & $1.21 \pm 0.09$ & $27.20 \pm 1.65$ \\
\hline PHF-8 & $0.42 \pm 0.05$ & $0.57 \pm 0.08$ & 26.32 & $1.36 \pm 0.12$ & $28.32 \pm 1.37$ \\
\hline PHF-9 & $0.40 \pm 0.04$ & $0.54 \pm 0.06$ & 25.93 & $1.35 \pm 0.14$ & $28.22 \pm 1.56$ \\
\hline
\end{tabular}

All values are reported as mean $\pm \mathrm{SD}, \mathrm{n}=3$ measurements.

Table 2: Composition of polyherbal formulation for dispersible tablets

\begin{tabular}{|c|c|c|c|c|c|c|c|c|c|}
\hline Ingredients (mg/tab) & PHF-1 & PHF-2 & PHF-3 & PHF-4 & PHF-5 & PHF-6 & PHF-7 & PHF-8 & PHF-9 \\
\hline Aqueous extracts & $25 \times 10=$ & $25 \times 10=$ & $25 \times 10=$ & $25 \times 10=$ & $25 \times 10=$ & $25 \times 10=$ & $25 \times 10=$ & $25 \times 10=$ & $25 \times 10=$ \\
\hline Powder (10 plants) & 250 & 250 & 250 & 250 & 250 & 250 & 250 & 250 & 250 \\
\hline$\beta$-cyclodextrin & 200 & 200 & 200 & 200 & 200 & 200 & 200 & 200 & 200 \\
\hline Crospovidone & 15 & 20 & 25 & -- & -- & -- & -- & -- & -- \\
\hline Sod. Starch glycolate & -- & -- & -- & 15 & 20 & 25 & -- & -- & -- \\
\hline Croscarmellose sodium & -- & -- & -- & -- & -- & -- & 15 & 20 & 25 \\
\hline Microcrystalline cellulose & 65 & 60 & 55 & 65 & 60 & 55 & 65 & 60 & 55 \\
\hline Sodium Saccharin & 10 & 10 & 10 & 10 & 10 & 10 & 10 & 10 & 10 \\
\hline Mg. Stearate & 5 & 5 & 5 & 5 & 5 & 5 & 5 & 5 & 5 \\
\hline Talc & 5 & 5 & 5 & 5 & 5 & 5 & 5 & 5 & 5 \\
\hline Total Weight & 550 & 550 & 550 & 550 & 550 & 550 & 550 & 550 & 550 \\
\hline
\end{tabular}

$\mathrm{PHF}=$ Polyherbal formulation

All the prepared formulations were subjected for evaluation of characteristic parameters like size, shape, color, and appearance. The prepared polyherbal dispersible tablets were non-sticky and look high-quality. The diameter and thickness of each formulated tablets were performed with 20 tablets by using a digital vernier scale during the physical study because it permits accurate measurements and provides exact information about variations between tablets of each formulation (table 3). The visualized the color and shape of all tablets were observed directly by naked eyes (fig. 1).

Table 3: Physical description of polyherbal dispersible tablets

\begin{tabular}{lll}
\hline S. No. & Parameter & Result \\
\hline 1. & Color & Yellowish-Brown \\
2. & Shape & Round, Biconvex \\
3. & Odor & Characteristic odor \\
4. & Taste & Pleasant taste \\
5. & Size in mm & \\
& i. Thickness & $5.12 \pm 0.08 \mathrm{~mm}$ \\
& ii. Diameter & $12.17 \pm 0.01 \mathrm{~mm}$ \\
\hline
\end{tabular}

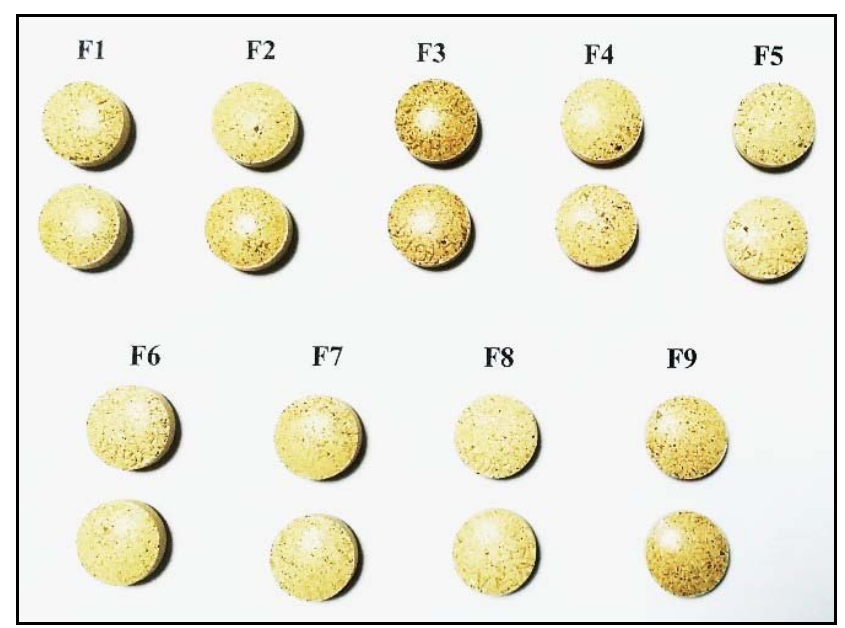

Fig. 1: Physical appearance of polyherbal dispersible tablets 


\section{Weight variation}

The weight variation of tablets was carried out to ensure that, each of the tablets contains the proper amount of drug. The test was performed by weighing 20 tablets individually using an analytical balance, then calculating the average weight and comparing the individual tablet weights (table 4). The percentage weight variation is calculated by using the eq. 6 .

$$
\% \text { wt variation }=\frac{\text { Average wt-Individual wt }}{\text { Average } w t} \times 100
$$

\section{Hardness}

The conformation of tablets for capping, abrasion or breakage under storage conditions, transportation, and handling before use depends on tablet hardness $\left(\mathrm{kg} / \mathrm{cm}^{2}\right)$. The hardness test was performed by using Monsanto hardness tester (Harrison's). The instrument measures the force required to break the tablet when the force (Kilogram-force) generated by anvils to the tablet. The tablet was placed between two anvils; the force applied to the anvils, and the crushing strength that causes the tablet to break was recorded, and the crushing strength test was performed on 20 tablets of each formulation (table 4).

\section{Friability}

The friability test was performed by using tablet friability tester (Veego). Twenty tablets of each formulation were weighed and tested at a speed of $25 \mathrm{rpm}$ for $4 \mathrm{~min}$ (100 rotations). After removing of dust, tablets were re-weighed, and friability percentage was calculated by the given eq. 7 , and the average value of all formulation is given in table 4 .

$\%$ Friability $=\frac{\text { Tablet } w t \text { before friability }- \text { Tablet wt after friability }}{\text { Tablet } w t \text { after friability }} \times 100$

Table 4: Physical properties of polyherbal dispersible tablets

\begin{tabular}{|c|c|c|c|c|c|}
\hline Formulation code & Average weight (mg) & Weight variation (\%) & Content uniformity (\%) & Hardness $\left(\mathrm{kg} / \mathrm{cm}^{2}\right)$ & Friability (\%) \\
\hline PHF-1 & $563.15 \pm 9.38$ & 2.34 & 102.38 & $2.98 \pm 0.13$ & 0.90 \\
\hline PHF-2 & $562.40 \pm 8.01$ & 2.20 & 101.25 & $2.91 \pm 0.09$ & 0.82 \\
\hline PHF-3 & $563.28 \pm 7.78$ & 2.36 & 105.05 & $2.99 \pm 0.14$ & 0.79 \\
\hline PHF-4 & $565.31 \pm 8.11$ & 2.71 & 103.10 & $3.00 \pm 0.12$ & 0.86 \\
\hline PHF-5 & $560.80 \pm 10.2$ & 1.93 & 099.85 & $2.94 \pm 0.13$ & 0.90 \\
\hline PHF-6 & $563.63 \pm 7.40$ & 2.42 & 101.80 & $2.95 \pm 0.12$ & 0.80 \\
\hline PHF-7 & $558.34 \pm 7.68$ & 1.22 & 098.96 & $2.96 \pm 0.16$ & 0.85 \\
\hline PHF-8 & $563.18 \pm 8.07$ & 2.34 & 102.00 & $3.02 \pm 0.18$ & 0.78 \\
\hline PHF-9 & $564.13 \pm 8.78$ & 2.50 & 099.68 & $2.97 \pm 0.11$ & 0.88 \\
\hline
\end{tabular}

All values are reported as mean $\pm S D, n=20$ tablets.

The maximum weight variation obtained was $2.50 \%$, which falls within the acceptable weight variation range, i.e., $\pm 5 \%$ hence passed the weight variation test. The hardness of prepared tablets was in the range of 2.94 to $3.02 \mathrm{~kg} / \mathrm{cm}^{2}$, which falls within the limit of not $<$ $3.0 \mathrm{~kg} / \mathrm{cm}^{2}$. None of the tablets showed friability value more than $0.90 \%$ which is less than the ideal limit, i.e., $1 \%$.

\section{Disintegration time}

The disintegration apparatus used for the study was determined by using USP (Electro lab-ED2 SAPO). It contains two basket rack assembly. Each basket rack assembly comprises 6 glass tubes that are 3 inches long, open at the top and held against 10 mesh screens at the bottom. Each tablet was placed in each basket tube, and the basket rack was dipped in a 1-L beaker of distilled water. The $37 \pm 2$ ${ }^{\circ} \mathrm{C}$ temperature was maintained throughout the study (table 5).

\section{Dispersion time}

The dispersion time of polyherbal dispersible tablets was observed by placing 2 tablets in $100 \mathrm{ml}$ of water in a beaker and gently stirred until dispersed completely. A smooth dispersion was obtained by passing through a sieve screen with a nominal mesh aperture (table $5)$.

Table 5: Disintegration and dispersion time of polyherbal dispersible tablet

\begin{tabular}{lll}
\hline Formulations & Disintegration time (Min) & Dispersion time (Min) \\
\hline PHF-1 & $02.08 \pm 0.62$ & $3.18 \pm 0.82$ \\
PHF-2 & $01.45 \pm 0.28$ & $2.30 \pm 0.60$ \\
PHF-3 & $01.10 \pm 0.10$ & $2.00 \pm 0.45$ \\
PHF-4 & $02.00 \pm 0.45$ & $3.00 \pm 0.78$ \\
PHF-5 & $02.18 \pm 0.51$ & $2.50 \pm 0.65$ \\
PHF-6 & $01.55 \pm 0.60$ & $2.24 \pm 0.58$ \\
PHF-7 & $02.15 \pm 0.55$ & $3.25 \pm 0.80$ \\
PHF-8 & $02.06 \pm 0.70$ & $2.55 \pm 0.71$ \\
PHF-9 & $01.50 \pm 0.58$ & $3.00 \pm 0.82$ \\
\hline
\end{tabular}

All values are reported as mean $\pm \mathrm{SD}, \mathrm{n}=3$ measurements.

Out of all the formulation, PHF-3 has passed the disintegration test by taking time i.e., $01.10 \pm 0.10 \mathrm{~min}$, which is less than ideal limits. The best PHF-3 has shown a good dispersion time and the complete dispersion was observed within $2.00 \pm 0.45$ min only. Hence the formulation was passed for the in vitro dispersion test.

Table 6: Stability data of the polyherbal dispersible tablet (PHF-3)

\begin{tabular}{|c|c|c|c|}
\hline \multirow[t]{2}{*}{ Time } & \multicolumn{3}{|c|}{ \% Drug content at different storage conditions } \\
\hline & $25^{\circ} \mathrm{C}$ and $60 \% \mathrm{RH}$ & $30{ }^{\circ} \mathrm{C}$ and $65 \% \mathrm{RH}$ & $40{ }^{\circ} \mathrm{C}$ and $75 \% \mathrm{RH}$ \\
\hline $1 \mathrm{mo}$ & 98.92 & 99.10 & 99.30 \\
\hline $2 \mathrm{mo}$ & 99.20 & 98.86 & 98.92 \\
\hline $3 \mathrm{mo}$ & 99.34 & 98.95 & 97.67 \\
\hline
\end{tabular}




\section{IR compatibility studies}

IR spectrum of the polyherbal formulation was obtained using IR spectrophotometer Perkin Elmer at Department of Pharmaceutical
Science, Bhimtal Campus, Kumaun University, Nainital. The potassium bromide was used in preparing samples by disk method, and measurement was attempted with the accumulation of 20 scans and resonation of $4 \mathrm{~cm}^{-1}$ over the range of 450 to $4000 \mathrm{~cm}^{-1}$ (table 7).

Table 7: Observed IR peaks of polyherbal extract formulation and their interpretation

\begin{tabular}{|c|c|c|c|c|}
\hline S. No. & Plant name & Observed peak $\left(\mathrm{cm}^{-1}\right)$ & Group present & Interpretation \\
\hline \multirow[t]{5}{*}{1.} & Angelica officinalis & 3290.77 & Alkynes group & 三C-H stretching \\
\hline & & 1587.00 & Aromatic ring & $\mathrm{C}-\mathrm{C}=\mathrm{C}$ symmetric stretch \\
\hline & & 1360.16 & Alkane group & $-\mathrm{C}-\mathrm{H}$ bending \\
\hline & & 1014.45 & Ester group & $\mathrm{C}-\mathrm{O}$ stretching \\
\hline & & 574.24 & Alkyl halide & $\mathrm{C}-\mathrm{Br}$ stretching \\
\hline \multirow[t]{4}{*}{2.} & Boerhavia diffusa & 3278.20 & Alkynes group & $\equiv \mathrm{C}-\mathrm{H}$ stretching \\
\hline & & 1335.12 & Nitro compound & $\mathrm{N}-\mathrm{O}$ asymmetric stretch \\
\hline & & 1011.85 & Ester group & C-O stretching \\
\hline & & 574.41 & Alkyl halide & $\mathrm{C}-\mathrm{Br}$ stretching \\
\hline \multirow[t]{4}{*}{3.} & Carica papaya & 3273.45 & Alkynes group & $\equiv \mathrm{C}-\mathrm{H}$ stretching \\
\hline & & 1338.78 & Nitro compound & $\mathrm{N}-\mathrm{O}$ asymmetric stretch \\
\hline & & 1012.28 & Ester group & $\mathrm{C}-\mathrm{O}$ stretching \\
\hline & & 572.23 & Alkyl halide & $\mathrm{C}-\mathrm{Br}$ stretching \\
\hline \multirow[t]{6}{*}{4.} & Cassia Fistula & 3296.59 & Alkynes group & $\equiv \mathrm{C}-\mathrm{H}$ stretching \\
\hline & & 2921.26 & Alkane group & $\mathrm{C}-\mathrm{H}$ stretching \\
\hline & & 1633.13 & Amine group & $\mathrm{N}-\mathrm{H}$ bending \\
\hline & & 1338.83 & Nitro group & $\mathrm{N}=0$ bending \\
\hline & & 1012.93 & Ester group & C-O stretching \\
\hline & & 573.40 & Alkyl halide & $\mathrm{C}-\mathrm{Br}$ stretching \\
\hline \multirow[t]{5}{*}{5.} & Cichorium intybus & 3274.07 & Alkynes group & $\equiv \mathrm{C}-\mathrm{H}$ stretching \\
\hline & & 1590.00 & Amine group & $\mathrm{N}-\mathrm{H}$ bending \\
\hline & & 1407.78 & Aromatic ring & $\mathrm{C}=\mathrm{C}$ stretching \\
\hline & & 1016.67 & Ester group & $\mathrm{C}-\mathrm{O}$ stretching \\
\hline & & 572.34 & Alkyl halide & C-Br stretching \\
\hline \multirow[t]{7}{*}{6.} & Ficus hispida & 3276.15 & Alkynes group & $\equiv \mathrm{C}-\mathrm{H}$ stretching \\
\hline & & 2922.75 & Alkane group & C-H stretching \\
\hline & & 1592.51 & Amine group & $\mathrm{N}-\mathrm{H}$ bending \\
\hline & & 1364.58 & Nitro group & $\mathrm{N}=0$ bending \\
\hline & & 1149.37 & Alcohol group & C-O stretching \\
\hline & & 1017.10 & Ether group & $=\mathrm{C}-\mathrm{O}-\mathrm{C}$ symmetric stretch \\
\hline & & 573.76 & Alkyl halide & C-Br stretching \\
\hline \multirow[t]{5}{*}{7.} & Fumaria Indica & 3276.35 & Alkynes group & $\equiv \mathrm{C}-\mathrm{H}$ stretching \\
\hline & & 1338.75 & Nitro group & $\mathrm{N}=\mathrm{O}$ bending \\
\hline & & 1075.72 & Alcohol group & C-O stretching \\
\hline & & 1013.38 & Ether group & C-O stretching \\
\hline & & 573.42 & Alkyl halide & $\mathrm{C}-\mathrm{Br}$ stretching \\
\hline \multirow[t]{4}{*}{8.} & Crataeva Nurvala & 3287.59 & Alkynes group & $\equiv \mathrm{C}-\mathrm{H}$ stretching \\
\hline & & 1338.87 & Nitro group & $\mathrm{N}-\mathrm{O}$ asymmetric stretch \\
\hline & & 1015.92 & Ether group & C-O stretching \\
\hline & & 572.06 & Alkyl halide & $\mathrm{C}-\mathrm{Br}$ stretching \\
\hline \multirow[t]{4}{*}{9.} & Solidago virgaurea & 3272.34 & Alkynes group & $\equiv \mathrm{C}-\mathrm{H}$ stretching \\
\hline & & 1340.81 & Nitro group & $\mathrm{N}=\mathrm{O}$ bending \\
\hline & & 1014.95 & Ether group & $\mathrm{C}-\mathrm{O}$ stretching \\
\hline & & 573.75 & Alkyl halide & $\mathrm{C}-\mathrm{Br}$ stretching \\
\hline \multirow[t]{4}{*}{10.} & Vitex Negundo & 3281.41 & Alkynes group & $\equiv \mathrm{C}-\mathrm{H}$ stretching \\
\hline & & 1339.35 & Nitro group & $\mathrm{N}=\mathrm{O}$ bending \\
\hline & & 1012.33 & Ether group & C-O stretching \\
\hline & & 528.05 & Carbon skeleton mode & C-C-O (for skeleton) \\
\hline
\end{tabular}

After the running spectra of significant peaks relating to major functional groups were identified, spectra of the successive sample of all compounds were compared with each other. The spectra are shown in fig. 5.1 to 5.10.

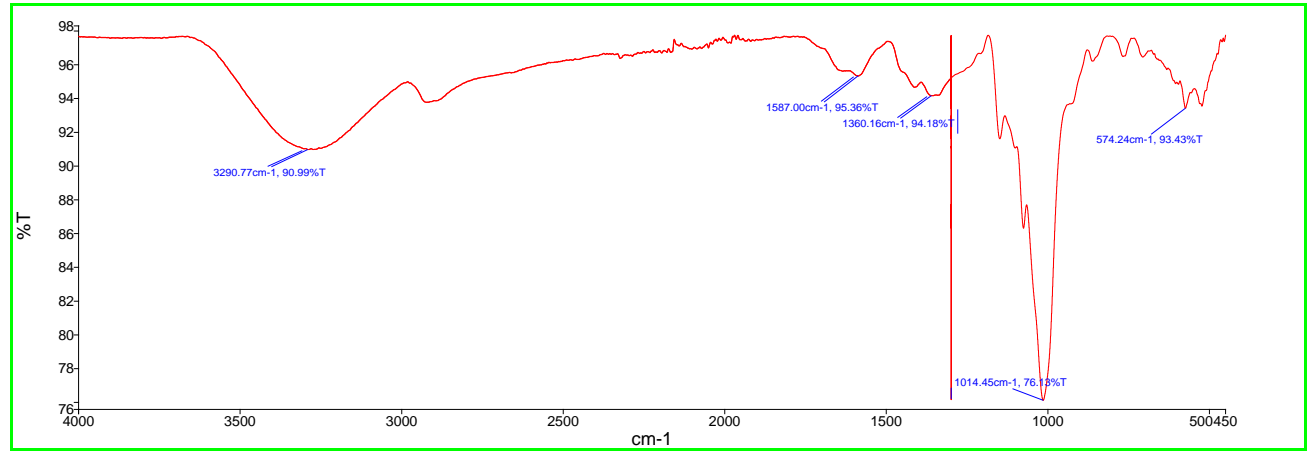

Fig. 5.1: IR spectrum of Angelica officinalis linn aqueous root extract 
The IR spectrum of Angelica officinalis (fig. 5.1) was observed and determines the characteristics of functional groups through different peaks i.e., $3290.77 \mathrm{~cm}^{-1}$ for alkynes group $(\equiv \mathrm{C}-\mathrm{H}$ stretching), $1587.00 \mathrm{~cm}^{-1}$ for aromatic ring ( $\mathrm{C}-\mathrm{C}=\mathrm{C}$ symmetric stretch), $1360.16 \mathrm{~cm}^{-1}$ for the alkane group (-C-H bending), the strong band at $1014.45 \mathrm{~cm}^{-1}$ forester group ( $\mathrm{C}-0$ stretching), and an alkyl halide group (C-Br stretching) found at $574.24 \mathrm{~cm}^{-1}$.
The IR spectrum of Boerhavia diffusa (fig. 5.2) was observed and determines the characteristics of functional groups through different peaks i.e., $3278.20 \mathrm{~cm}^{-1}$ for alkynes group (三C-H stretching), $1335.12 \mathrm{~cm}^{-1}$ for nitro compound (N-O asymmetric stretch), the very strong band observed at $1011.85 \mathrm{~cm}^{-1}$ for the ester group (C-0 stretching), and the wagging vibration of the alkyl halide group (CBr stretching) was observed at $574.24 \mathrm{~cm}^{-1}$.

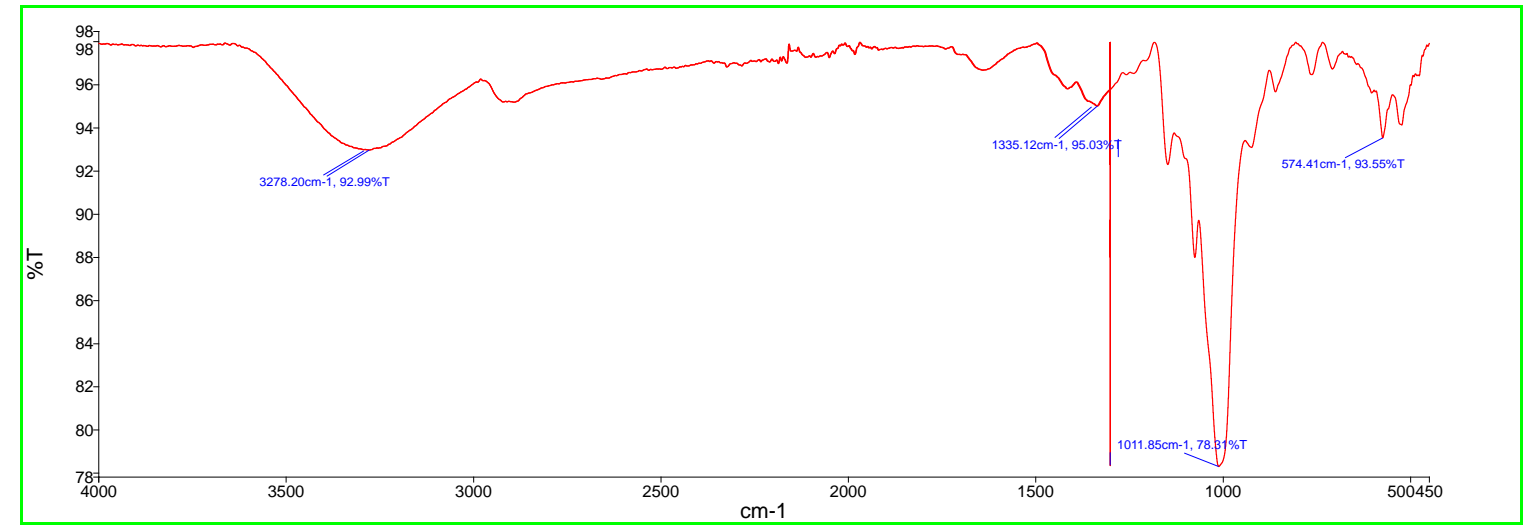

Fig. 5.2: IR spectrum of Boerhavia diffusa linn aqueous root extract

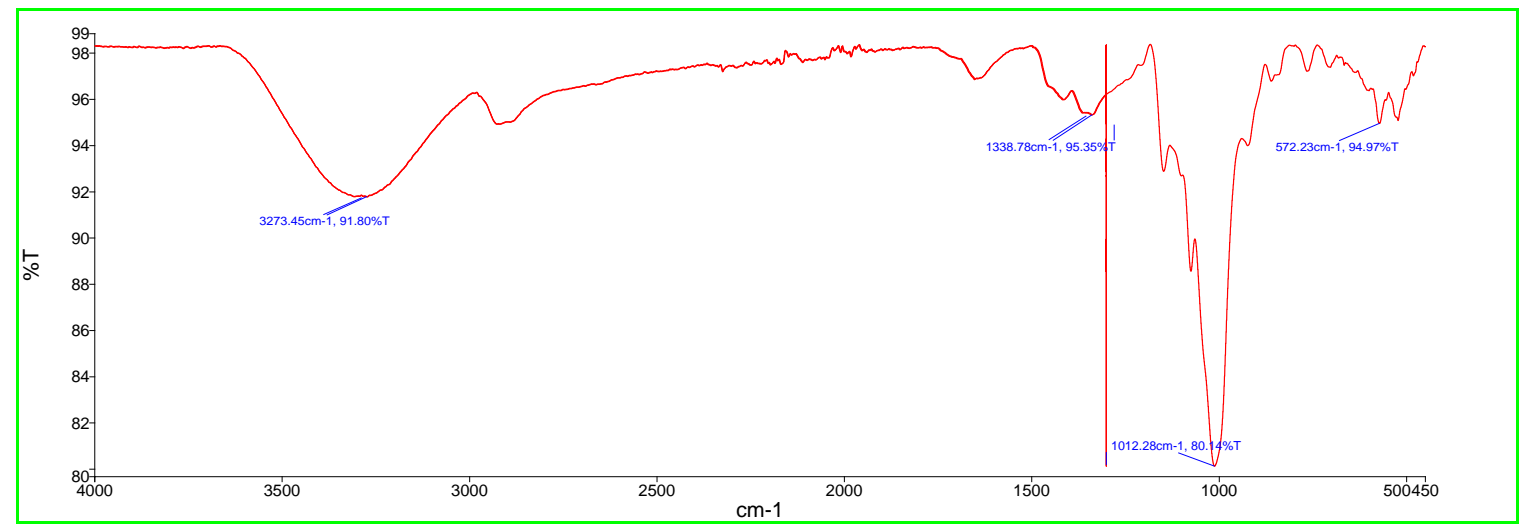

Fig. 5.3: IR spectrum of Carica papaya linn aqueous root extract

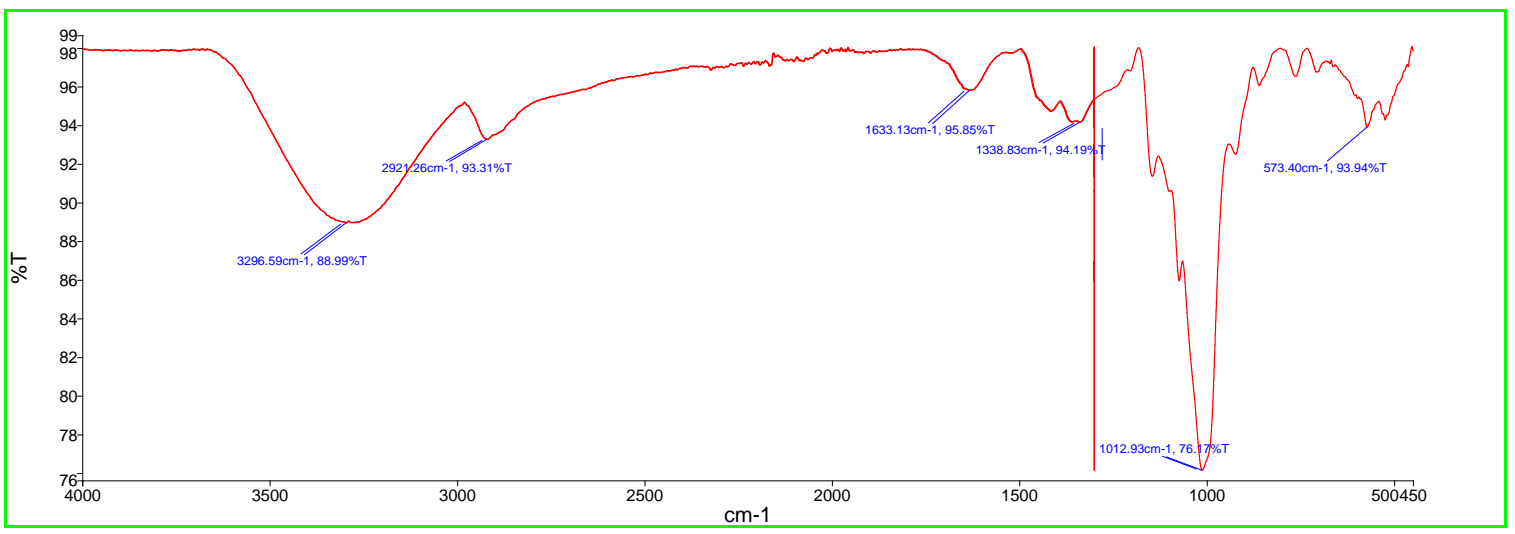

Fig. 5.4: IR spectrum of Cassia fistula linn aqueous root extract

The IR spectrum of Carica papaya (fig. 5.3) shows different peaks to determine the characteristics of functional groups as $3273.45 \mathrm{~cm}^{-1}$ for alkynes group ( $\equiv \mathrm{C}-\mathrm{H}$ stretching), the peak at $1338.78 \mathrm{~cm}^{-1}$ was assigned as asymmetric for nitro compound ( $\mathrm{N}-\mathrm{O}$ stretch), the intensity band at $1012.28 \mathrm{~cm}^{-1}$ corresponds to the ester group (C-O stretching), and the strong band observed at $572.23 \mathrm{~cm}^{-1}$ for alkyl halide group ( $\mathrm{C}-\mathrm{Br}$ stretching).

The IR spectrum of Cassia fistula (fig. 5.4) was observed to determine the characteristics of functional groups by different peaks 
viz. the peak observed at $3296.59 \mathrm{~cm}^{-1}$ is assigned to the stretching vibration of $\equiv \mathrm{C}-\mathrm{H}$ (alkynes) group. The band in the region around $2921.26 \mathrm{~cm}^{-1}$ observed for $\mathrm{C}-\mathrm{H}$ stretching (alkane group), a strong peak at $1633.13 \mathrm{~cm}^{-1}$ assigned toward $\mathrm{N}-\mathrm{H}$ bending vibration (amine group). The intensity band at $1338.83 \mathrm{~cm}^{-1}$ for the nitro group ( $\mathrm{N}=0$ bending), a strong peak at $1012.93 \mathrm{~cm}^{-1}$ for an ester group (C-O stretching) and the alkyl halide group (C-Br stretching) was observed at $573.40 \mathrm{~cm}^{-1}$.

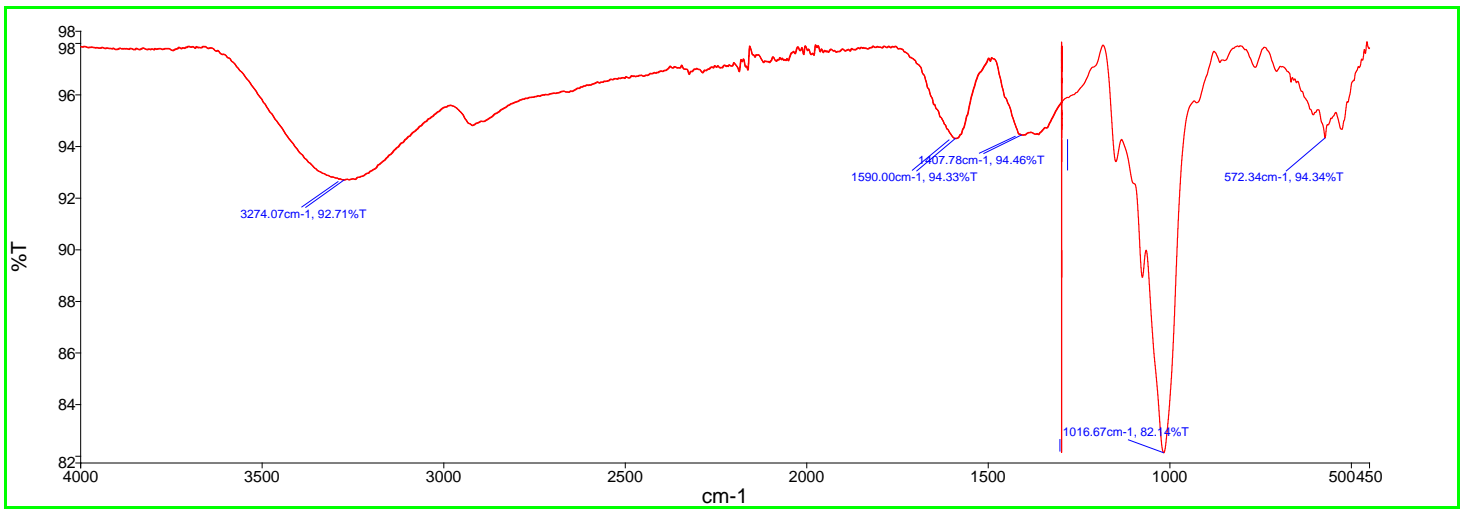

Fig. 5.5: IR spectrum of Cichorium intybus linn aqueous root extract

The IR spectrum of Cichorium intybus (fig. 5.5) was observed and determines the characteristics of functional groups through different peaks i.e., $3274.07 \mathrm{~cm}^{-1}$ for alkynes group ( $\equiv \mathrm{C}-\mathrm{H}$ stretching), the intensity band at $1590.00 \mathrm{~cm}^{-1}$ for $\mathrm{N}-\mathrm{H}$ (amine) group, the strong peak observed at $1407.78 \mathrm{~cm}^{-1}$ for $\mathrm{C}=\mathrm{C}$ stretching (aromatic ring). The peak observed at $1016.67 \mathrm{~cm}^{-1}$ assigned to the stretching vibration of $\mathrm{C}-\mathrm{O}$ (ester) group, and the wagging vibration of the alkyl halide group (C-Br stretching) was observed at $572.34 \mathrm{~cm}^{-1}$.

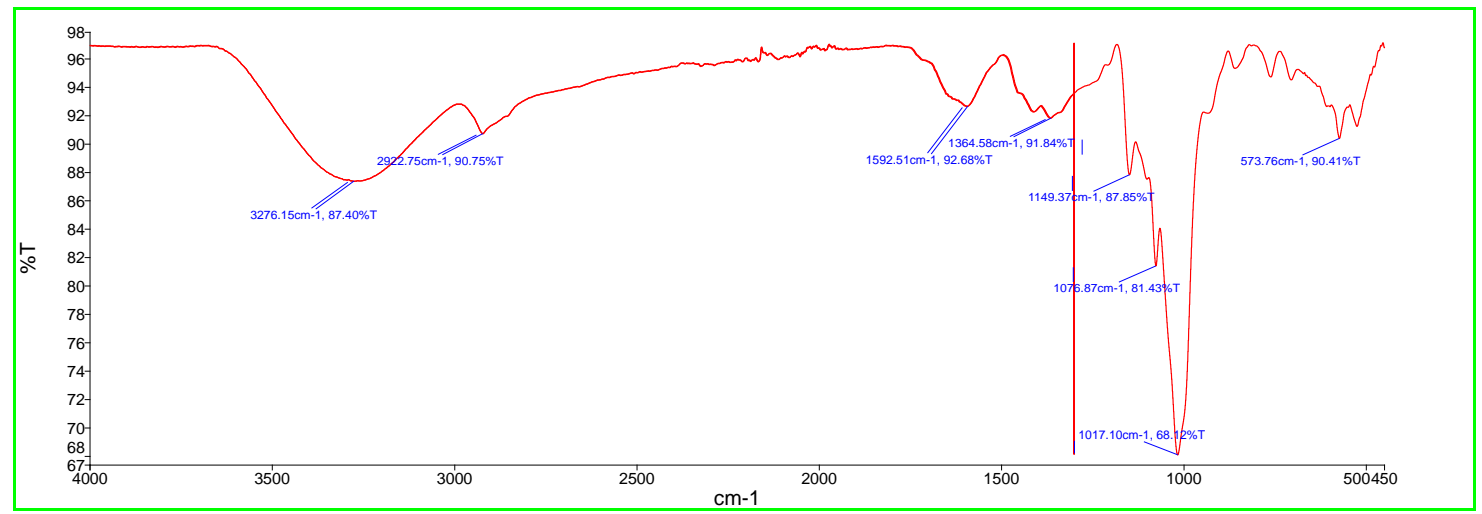

Fig. 5.6: IR spectrum of Ficus hispida linn aqueous root extract

The IR spectrum of Ficus hispida (fig. 5.6) shows different peaks to determine the characteristics of functional groups as $3276.15 \mathrm{~cm}^{-1}$ for alkynes group (三C-H stretching), and a strong peak at 2922.75 $\mathrm{cm}^{-1}$ observed for an alkane group (C-H stretching). The intensity band at $1592.51 \mathrm{~cm}^{-1}$ assigned for $\mathrm{N}-\mathrm{H}$ (amine) group and the strong peak observed at $1364.58 \mathrm{~cm}^{-1}$ for $\mathrm{N}=0$ bending (nitro group). The peak at $1149.37 \mathrm{~cm}^{-1}$ observed for alcohol group (C-0 stretching), the intensity band at $1017.10 \mathrm{~cm}^{-1}$ was assigned as an asymmetric stretch for $=\mathrm{C}-\mathrm{O}-\mathrm{C}$ (ether) group and the strong band observed at $573.76 \mathrm{~cm}^{-1}$ for alkyl halide group (C-Br stretching).

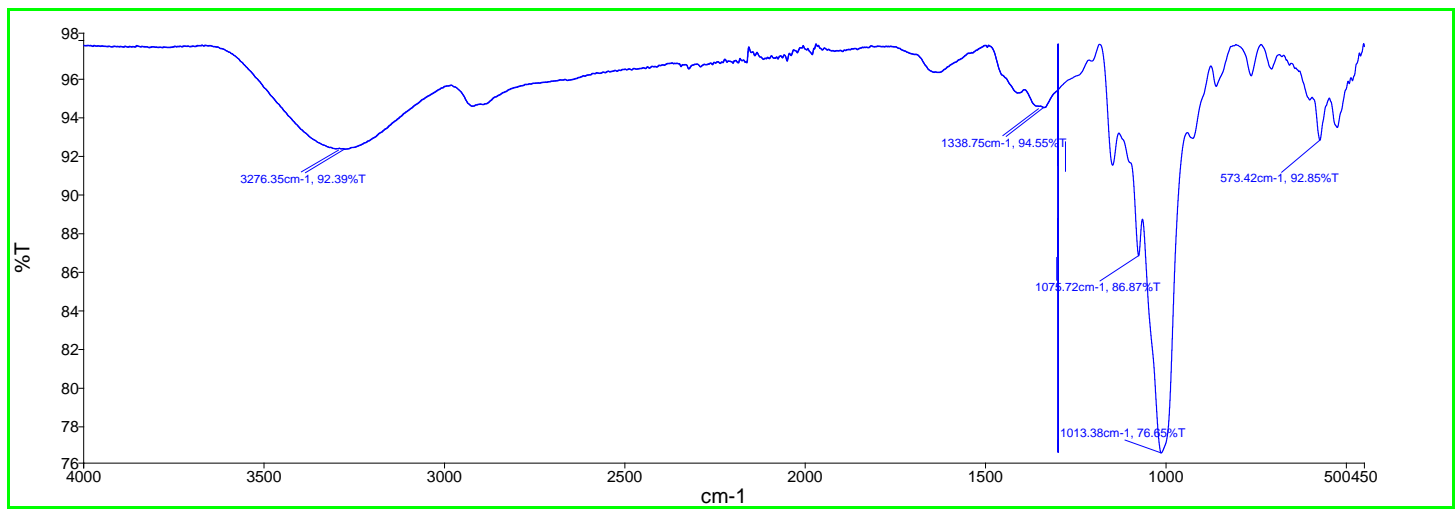

Fig. 5.7: IR spectrum of Fumaria indica linn aqueous root extract 
The IR spectrum of Fumaria indica (fig. 5.7) was observed for determining the characteristics of functional groups by different peaks viz. the peak observed at $3276.35 \mathrm{~cm}^{-1}$ is assigned to the stretching vibration of $\equiv \mathrm{C}-\mathrm{H}$ (alkynes) group. The strong band at $1338.75 \mathrm{~cm}^{-1}$ observed for $\mathrm{N}=0$ bending (nitro group), a strong peak at $1075.72 \mathrm{~cm}^{-1}$ assigned toward $\mathrm{C}-\mathrm{O}$ stretching (alcohol group). A strong peak at $1013.38 \mathrm{~cm}^{-1}$ for the ester group (C-O stretching) and the alkyl halide group (C-Br stretching) was observed at $573.42 \mathrm{~cm}^{-1}$.

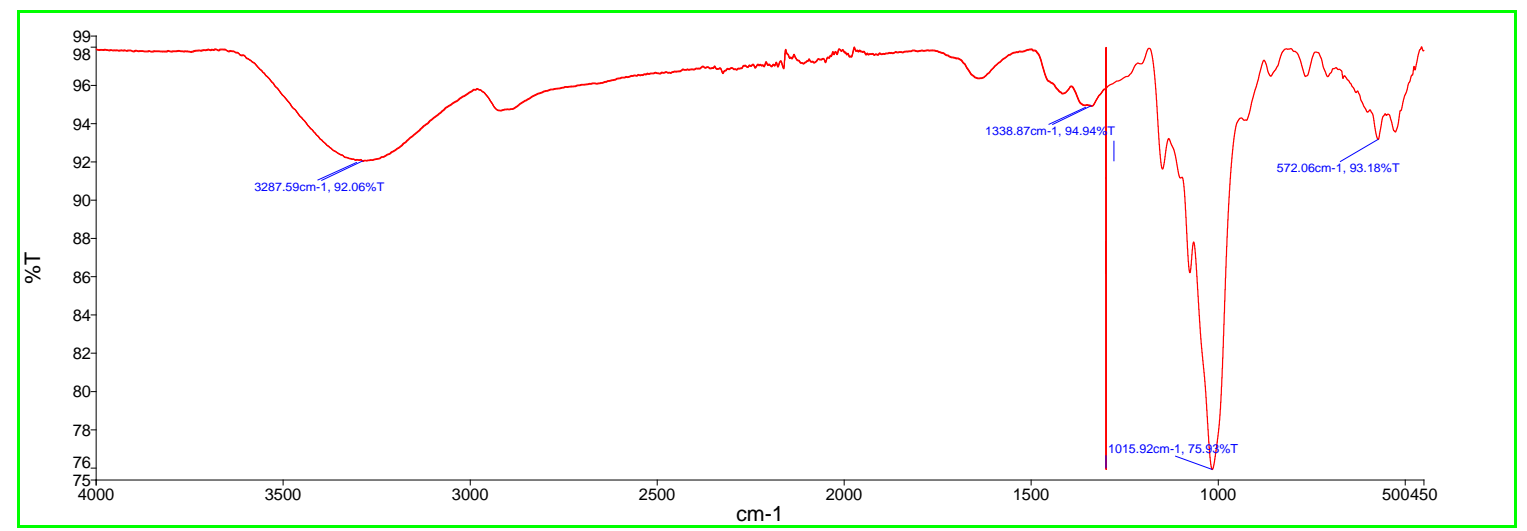

Fig. 5.8: IR spectrum of Crataeva nurvala linn aqueous root extract

The IR spectrum of Crataeva nurvala (fig. 5.8) shows different peaks to determine the characteristics of functional groups as $3287.59 \mathrm{~cm}^{-1}$ for alkynes group ( $\equiv \mathrm{C}-\mathrm{H}$ stretching), the peak at $1338.87 \mathrm{~cm}^{-1}$ was assigned as asymmetric for nitro compound (N-O stretch), the intensity band at $1015.92 \mathrm{~cm}^{-1}$ corresponds to the ether group ( $\mathrm{C}-0$ stretching), and the strong band observed at $572.06 \mathrm{~cm}^{-1}$ for alkyl halide group (C-Br stretching).
The IR spectrum of Solidago virgaurea (fig. 5.9) was observed and determines the characteristics of functional groups through different peaks i.e., $3272.34 \mathrm{~cm}^{-1}$ for alkynes group ( $\equiv \mathrm{C}-\mathrm{H}$ stretching), the intensity band at $1340.81 \mathrm{~cm}^{-1}$ for $\mathrm{N}=0$ (nitro) group. The peak observed at $1014.95 \mathrm{~cm}^{-1}$ assigned to the stretching vibration of C-O (ether) group, and the wagging vibration of the alkyl halide group (C-Br stretching) was observed at $573.75 \mathrm{~cm}^{-1}$.

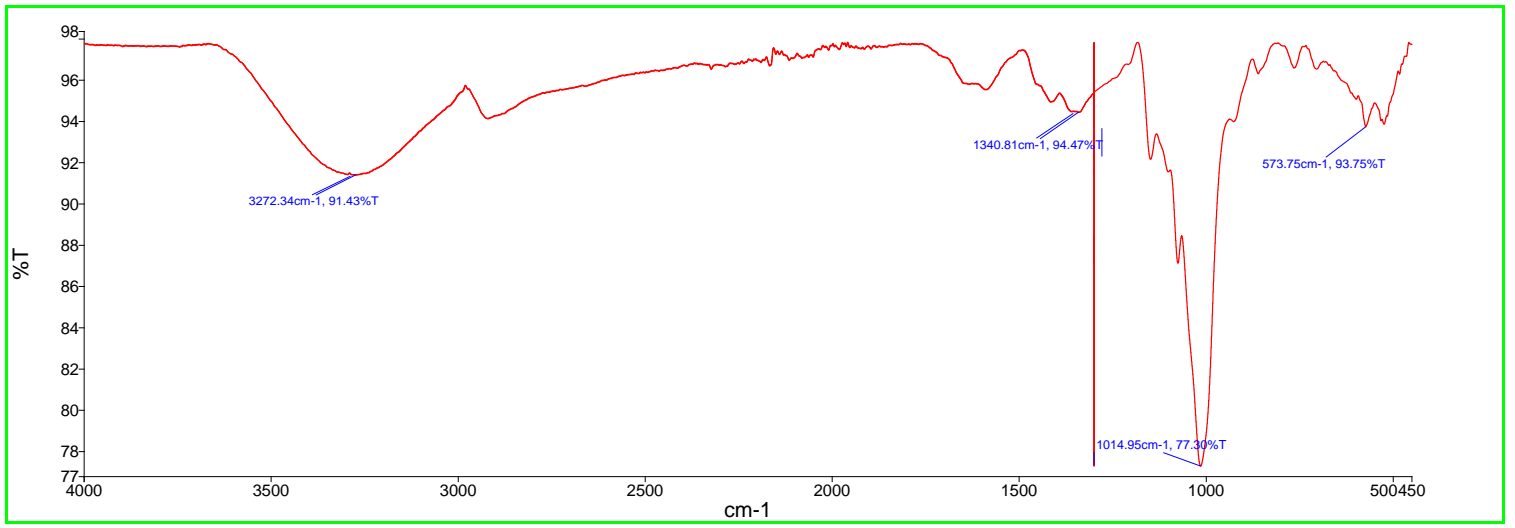

Fig. 5.9: IR spectrum of Solidago virgaurea linn aqueous root extract

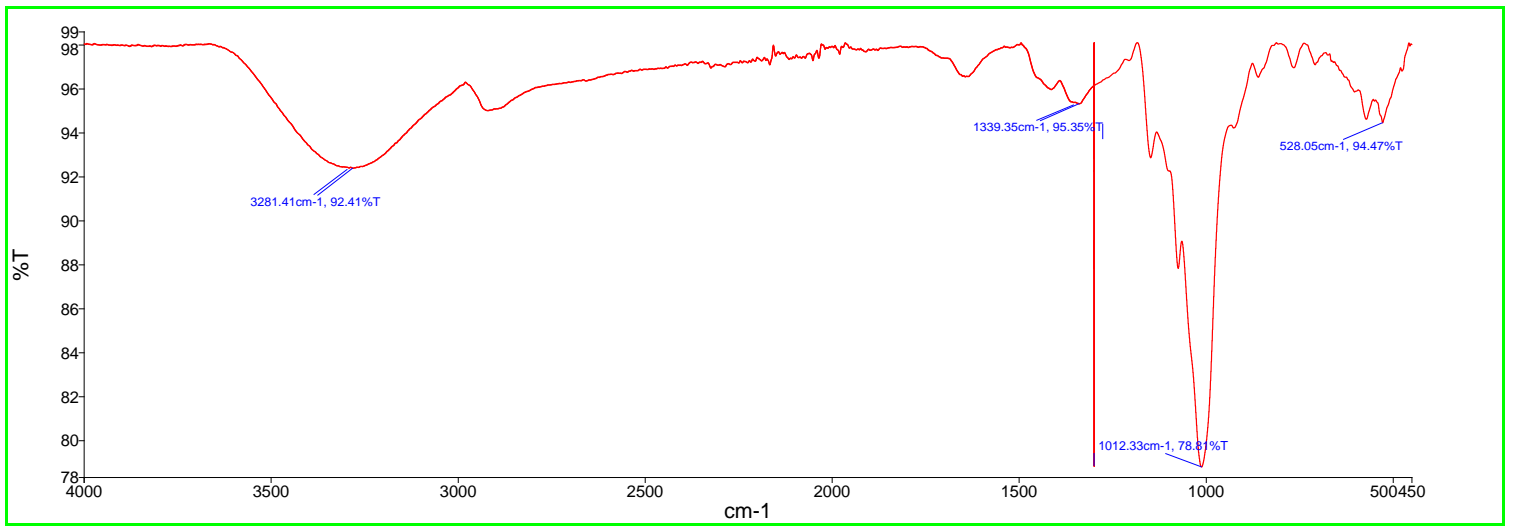

Fig. 5.10: IR spectrum of Vitex negundo linn aqueous root extract 
The IR spectrum of Vitex negundo (fig. 5.10) was observed for determining the characteristics of functional groups by different peaks viz. the peak observed at $3281.41 \mathrm{~cm}^{-1}$ is assigned to the stretching vibration of $\equiv \mathrm{C}-\mathrm{H}$ (alkynes) group. The strong band at $1339.35 \mathrm{~cm}^{-1}$ observed for $\mathrm{N}=\mathrm{O}$ bending (nitro group). A strong peak at $1012.33 \mathrm{~cm}^{-1}$ for the ether group (C-0 stretching) and the carbon skeleton mode (C-C-0) was observed at $528.05 \mathrm{~cm}^{-1}$.

The various components of the prepared polyherbal dispersible tablet formulations are shown in table 2. The formulation containing polyherbal drugs selected for preparing dispersible tablets were identified using published standard methods viz. powder characteristics, powder micro-meritics, drug content uniformity test, disintegration and dispersion time, stability study, and IR spectroscopy for drug excipients interaction study [29]. Organoleptic properties of prepared polyherbal dispersible tablet show the yellowish-Brown in color, almost round with characteristic odors and pleasant taste (fig. 1). The average thickness of tablets $5.12 \pm 0.08 \mathrm{~mm}$ and average diameter $12.17 \pm 0.01 \mathrm{~mm}$ was recorded during the evaluation and development of tablets (table 3) [30].

The micromeritic properties of formulations containing aqueous root extracts powder used for preparation of polyherbal dispersible tablets observed that, the formulation PHF- 3 has passed and shows all excellent properties viz. bulk density $(0.35 \pm 0.03 \mathrm{gm} / \mathrm{ml})$, tapped density $(0.49 \pm 0.07 \mathrm{gm} / \mathrm{ml})$, compressibility $(28.57 \%)$, Hausner ratio $(1.40 \pm 0.13)$, and Angle of repose $\left(24.35 \pm 1.00^{\circ}\right)$, which was comparable as per IP standard (table 1). PHF-3 has also shows the best physical properties i.e. average weight $(563.28 \pm 7.78 \mathrm{mg})$, weight variation $(2.36 \%)$, content uniformity $(105.05 \%)$, hardness $\left(2.99 \pm 0.14 \mathrm{~kg} / \mathrm{cm}^{2}\right)$, and friability $(0.79 \%)$ as compare to other fast dissolving tablets containing aqueous root extract of polyherbal formulations (table 4).

The disintegration time of dispersible tablets containing aqueous root extract of best polyherbal formulations PHF-3 was recorded in the acidic buffer $(1.10 \pm 0.10 \mathrm{~min})$ and the dispersion time of the same formulation reported as $2.00 \pm 0.45$ min only rated as best formulation as compared to other formulations (table 5). The stability study of polyherbal dispersible tablets for three months at a different condition was acceptable as per IP standard (table 6), and IR spectra of polyherbal formulations containing aqueous root extracts confirmed their stability, identity and purity (fig. 5.1 to fig. 5.10) $[31,32]$.

\section{CONCLUSION}

The results from the angle of repose, Carr's index and Hausner's ratio showed that the powder mixtures possess good flow properties. The physical properties of PHF-1 to PHF-9 were determined for the uniformity in weight, hardness, drug content and friability which have complied with the official requirements, and comply with the official limits mentioned in IP 2010. The PHF-3 showed good disintegration property and in vitro dispersion time as compare to other formulation. The FTIR spectroscopy suggests that the absence of any chemical interaction between the polyherbal extract and the excipients used in the dispersible tablet. The stable peaks of the drug remained unchanged in the mixtures shows characteristic functional groups like alkynes group, aliphatic amines, alkyl halides, an aromatic group, alkanes, alcohols, and the ester possess the various medicinal properties. The PHF-3 kept for stability studies and observed that it was reproducible even on stored for three months.

\section{ACKNOWLEDGMENT}

The authors are thankful to the Director of the Department of Pharmaceutical Science, Kumaun University Nainital, India for providing us such type of facilities to do our research work peacefully.

\section{AUTHORS CONTRIBUTIONS}

The entire authors have contributed equally

\section{CONFLICT OF INTERESTS}

The authors declared that none conflicts of interest concerning the authorship

\section{REFERENCES}

1. Hankey A. Ayurveda and the battle against chronic disease: an opportunity for ayurveda to go mainstream? J Ayurveda Integ Med 2010;1:9-12.

2. Chaudhary A, Singh N. Contribution of world health organization in the global acceptance of ayurveda. J Ayurveda Integ Med 2011;2:179-86.

3. Parasuraman S, Thing GS, Dhanaraj SA. Polyherbal formulation: concept of ayurveda. Pharmacogn Rev 2014;8:73-80.

4. Pandey MM, Rastogi S, Rawat AKS. Indian traditional ayurvedic system of medicine and nutritional supplementation. J Evidence Based Complementary Altern Med 2013:1-12. http://dx.doi.org/10.1155/2013/376327

5. Garg V, Dhar VJ, Sharma A, Dutt R. Facts about standardization of herbal medicine: a review. Zhong Xi Yi Jie He Xue Bao 2012;10:1077-83.

6. Awasthi H, Mani D, Nath R, Nischal A, Usman K, Khattri S Standardization, preparation and evaluation of an Ayurvedic polyherbal formulation in a capsule dosage form suitable for use in clinical trials. Indo Am J Pharm Res 2014;4:4093-9.

7. Mathew L, Babu S. Phytotherapy in India: the transition of tradition to technology. Curr Bot 2011;2:17-22.

8. Srivastava S, Lal VK, Pant KK. Polyherbal formulations based on Indian medicinal plants as antidiabetic phytotherapeutics. Phytopharmacology 2012;2:1-15.

9. Kapoor VK, Singla S. Herb-drug interactions-an update on synergistic interactions. J Alt Med Res 2015;1:1-11.

10. Gurley BJ. Pharmacokinetic herb-drug interactions (Part 1): Origins, mechanisms, and the impact of botanical dietary supplements. Planta Med 2012;78:1478-89.

11. Rawat R, Vashistha DP. Common herbal plant in Uttarakhand, used in the popular medicinal preparation in ayurveda. Int $\mathrm{J}$ Pharmacogn Phytochem Res 2011;3:64-73.

12. Kulkarni, Raghavendra G. Extraction of roots of quintics by division method. Int J Mathem Edu Sci Tech 2009;40:407-10.

13. Rajab NA. Preparation and in vitro evaluation of lacidipine oral liquid-solid tablet as an approach of solubility and dissolution rate enhancement. Int J Appl Pharm 2018;10:145-53.

14. Parfati N, Rani KC, Charles N, Geovanny V. Preparation and evaluation of atenolol- $\beta$-cyclodextrin orally disintegrating tablets using co-process crospovidone-sodium starch glycolate. Int J Appl Pharm 2018;10:190-94.

15. Agnihotri A, Singh V. Formulation development, and evaluation of antidiabetic polyherbal tablet. Pharma Innov J 2014;3:1-3.

16. Nagar P, Singh K, Chauhan I, Madhu V, Yasir M, Khan A, et al. Orally disintegrating tablets: formulation, preparation, techniques, and evaluation. J Appl Pharm Sci 2011;4:35-45.

17. Tiwari OP, Sharma M. Formulation, and development of fast dissolving tablet of methanolic extract of some traditionally used medicinal plants for arthritis. Int J Appl Pharm Biol Res 2017;8:28-32.

18. Mishra US, Murthy PN, Pasa G, Mishra D. Formulation development and evaluation of herbal tablet containing methanolic extract of Butea frondosa. Int J Inst Pharm Life Sci 2011;1:1-15.

19. Christianah I, Ekere K, Judith O, Olayemi O, Darlington O, et al. Phytopharmaceutical properties of herbal teas circulating in the Nigerian market. Afr J Pharm Pharmacol 2016;10:1007-13.

20. Shah RB, Tawakkul MA, Khan MA. Comparative evaluation of flow for pharmaceutical powders and granules. AAPS Pharm Sci Tech 2008;9:250-8.

21. Kagalkar AA, Nanjwade BK, Bagli RS. Development and evaluation of herbal fast dissolving tablets of Tectona grandis Linn. Int J Pha Res Rev 2014;3:6-14.

22. Monton C, Saingam W, Suksaeree J, Sakunpak A, Kraisintu K. Preformulation and physical properties study of fast disintegrating tablets from Thai traditional formula. Int $\mathrm{J}$ Pharm Pharm Sci 2014;6:431-4.

23. US department of health and human services food and drug administration center for drug evaluation and research. Guidance for industry: orally disintegrating tablets. New Hampshire eve: Division of drug information food and drug administration; 2008. 
24. Hahm HA, Augsburger LL. Orally disintegrating tablets and related tablet formulations. In: Pharmaceutical Dosage Forms: Tablets. New York: Informa Healthcare; 2008. p. 293-312.

25. Disch L, Drewe J, Fricker G. Dissolution testing of herbal medicines: challenges and regulatory standards in Europe, the United States, Canada, and Asia. Disso Technol 2017:6-12. Doi.org/10.14227/DT240217P6

26. Guidance for industry, ICH topic Q1A (R2) stability testing of new drug substances and products. Eur Med Agency (EMEA) 2003;CPMP/ICH/2736/99.

27. Bunaciu AA, Aboul-Enein HY, Fleschin S. Recent applications of fourier transform infrared spectrophotometry in herbal medicine analysis. Appl Spectro Rev 2011;46:251-60.

28. Kumar PP, Pillai S, Michael M, Kavya K, Kumar P, Iqbal SS, et al. Fourier transform infrared (FT-IR) spectral studies of a novel polyherbal formulation of anti-obesity drug. J Med Sci-Tech 2015; 4:55-7.

29. Patra A, Jha S, Murthy PN, Sampathy S, Kumar T. Preliminary phytochemical screening and antipyretic activity of leaf and root of Hygrophila spinosa T. anders. Pharmacol Online 2009;1:449-53.

30. Kala M, Kumar T, Singh HK. Effect of bacosides enriched standardized extract of Bacopa monniera (BESEB-CDRI-08) on lipid profile and blood pressure of postmenopausal women: a pilot study. Pharma Innov J 2015;4:91-5.

31. Maurya H, Kumar T. Formulation, characterization and pharmacological evaluation of anti-inflammatory polyphyto matrix tablet as a novel drug delivery system. Indian J Pharm Biol Res 2016;4:50-7.

32. Gupta S, Gahlot K. Formulation and evaluation of herbal antidemential tablets. Asian J Pharm Clin Res 2012;5:148-53. 